\title{
PANDANGAN KONTEMPORER \\ KERAJAAN SERIBU TAHUN \\ Suatu Studi Teologi Perjanjian Baru Tentang Milenium
}

\section{Nicodemus Yuliastomo}

\section{A. Pendahuluan.}

Pembahasan tentang kerajaan seribu tahun selalu dimulai dengan pertanyaan-pertanyaan: Apakah kerajaan seribu tahun dalam Wahyu $20: 1-7$ diartikan secara harafiah atau figuratif ? Apakah kerajaan seribu tahun sudah berlangsung sekarang atau nanti sesudah kedatangan Yesus keduakali?

Sampai sekarang gereja memiliki pemahaman yang tidak sama tentang ajaran ini. Bahkan "hampir dari awal gereja memperdebatkan apakah masa "Milenium" merupakan periode seribu tahun di akhir zaman menuju kekekalan ? Gereja mula-mula melihat topik ini berdasarkan kepada pertanyaan sentral tentang otoritas dari kitab Wahyu."

Pembahasan topik ini memang tidaklah mudah, dari sudut teologi Perjanjian Baru selain referensi yang terbatas, kitab Wahyu sebagai kitab terakhir Perjanjian Baru juga penuh dengan berbagai teka-teki yang mempunyai karakteristik berbeda dengan Alkitablainnya. Tidak ada teori tunggal tentang wacana milenium, dan setiap pembahasan harus siap untuk berseberangan dengan konsep yang lain. Walaupun demikian setiap usaha untuk terus menggali rahasia milenium tidak boleh berhenti karena berbagai kesulitan dan konsekuensi yang ada.

Sebagai pintu awal pembuka jalan, penulis menganggap bijaksana kalau spirit penulisan tema ini didasarkan kepada apa yang dikatakan George Eldon Ladd: "Pendekatan yang paling mudah terhadap kitab Wahyu adalah mengikuti tradisi penafsiran tertentu dari seseorang sebagai pandangan yang benar, dan mengesampingkan yang lain;

namun penafsiran yang baik harus berupaya mengenal metode-metode penafsir yang lain agar supaya ia dapat menguji dan mempertajam pandangannya sendiri."

\section{B. Kitab Wahyu dan Milenium.}

Untuk memahami tentang kerajaan seribu tahun dalam Wahyu 20, tidak bisa tidak harus dimulai dengan memahami secara menyeluruh konteks kitab itu sendiri. Hal ini bukan saja untuk mendapatkan pijakan yang tepat tetapi juga karena sebagai kitab nubuatan kitab Wahyu memiliki karakter yang berbeda dengan buku-buku lainnya. Selain penuh dengan simbolsimbol, penglihatan-penglihatan, binatang-binatang aneh, materai dan pengungkapan kata sangkakala serta cawan, Leon Morris juga mengatakan : Kitab ini menyajikan suatu jenis kesusastraan yang cukup lazim pada waktu gerakan Kristen dimulai, namun sekarang tidak dipakai orang lagi. Karena itu dibutuhkan suatu usaha khusus apabila kita mau memahami apa yang dikatakan penulis kepada kita."

\section{Kitab Apokaliptik.}

Kata apokaliptik menunjuk kepada suatu jenis tulisan sastra Yahudi dan Kristen. Bagi bangsa Yahudi sastra ini "merupakan hasil dari pengharapan yang tidak dapat dihancurkan." Tulisan jenis ini muncul dari suatu sejarah yang "khusus." Dan "menyajikan penyataan-penyataan 
Allah yang menerangkan penyebab berkuasanya kejahatan, dan membuka tabir rahasia sorgawi serta menjanjikan kedatangan kerajaan-Nya dengan segera bagi orang-orang yang dilanda penderitaan."

Merril C. Tenney menguraikan beberapa ciri kitab apokaliptik: "Pertama, keputusasaan yang besar dalam menghadapi keadaan yang sedang berlangsung dan suatu pengharapan yang sama besarnya akan campur tangan ilahi di masa depan ; Kedua, penggunaan bahasa simbolik, impian-impian, dan penglihatan-penglihatan; Ketiga, ditampilkannya kuasa-kuasa surgawi dan Iblis sebagai utusan dan perantara dalam perkembangan rencana Allah; Keempat, nubuat tentang malapetaka hebat yang akan mengenai orang-orang fasik dan yang secara ajaib akan melewati orang-orang yang benar, dan; Kelima, adakalanya pemalsuan namanama penulisnya dengan tokoh-tokoh sejarah kitab Suci yang menonjol, seperti Ezra atau Henokh."

Berkaitan dengan akhir zaman, apokaliptik menunjuk pada suatu jenis eskatologi yang meliputi ciri-ciri tertentu: " Pertama, dualisme. Para nabi menempatkan penyelamatan terakhir dalam dunia ini. Adanya pertentangan zaman ini dan zaman yang akan datang ; Kedua, determinisme. Kedatangan zaman baru bergantung seutuhnya dalam tangan Tuhan, tidak dapat dipercepat atau diperlambat oleh manusia; Ketiga, pesimisme. Sikap pesimis tentang kemenangan akhir dari Kerajaan Allah. Meskipun demikian tetap berharap akan kedatangan zaman baru ; Empat, sikap etis yang pasif. Penulis-penulis apokaliptik tidak memberitakan penghukuman Allah atas umat-Nya seperti dilakukan para nabi."

Kitab Wahyu tergolong apokaliptik "kitab ini ditulis di tengah-tengah penganiayaan besar. Penganiayaan yang dianggap pada masa pemerintahan Kaisar Domitian." Walaupun demikian mengenai kitab Wahyu "penulis menyatakan namanya, dan menganggap pembaca sudah mengenalnya, bukan sebagai tokoh dari masa yang lampau, tetapi sebagai sesama dengan mereka yang dituju olehnya dalam persoalan-persoalan mereka."

Sebagai kitab apokaliptik, George Eldon Ladd membagi isi berita Wahyu di dalam tiga bagian: "Pertama, masalah kejahatan. Wahyu menubuatkan adanya periode singkat kejahatan yang dahsyat yang terjadi dalam sejarah pada akhir zaman. Ia diperkenankan memerangi gereja dan melaksanakan pemerintahan yang menguasai seluruh dunia (Wahyu 13:1-10). Manusia akan diperhadapkan kepada pilihan menyangkal Kristus atau mati dibunuh. Sejumlah orang yang tak terhitung banyaknya dari segala bangsa akan dibunuh karena kesetiaan mereka pada Anak Domba ( 7:9-17) ; Kedua, datangnya murka. Wahyu menggambarkan sesuatu yang tidak diajarkan di tempat lain dalam Alkitab, yaitu bahwa masa kesengsaraan besar juga akan menjadi masa penjatuhan hukuman Allah ke atas manusia, dan ; Ketiga, kedatangan kerajaan. Kedatangan Kerajaan Allah digambarkan dalam dua warna, yaitu kehancuran kejahatan dan berkat kehidupan kekal."

\section{Penafsiran Kitab Wahyu.}

Rasul Yohanes merupakan penulis kitab ini. Wahyu ditulis ketika gereja perdana mengalami "penganiayaan dan kesulitan." "Penganiayaan terjadi pada periode pemerintahan Domitianus, yakni 95 M." Menurut William Barclay: "Yohanes, ketika melihat hal-hal ini (penglihatan), berada di Pulau Patmos, dihukum kerja paksa di pertambangan oleh Kaisar Domitianus." "Yohanes menulis kitab Wahyu untuk membesarkan hati orang-orang Kristen abad pertama 
yang sedang mengalami penderitaan besar." "Kitab Wahyu awalnya dikirimkan kepada tujuh gereja lokal yang ada di Asia Kecil." Sedangkan tema dari kitab Wahyu adalah "The victory of Christ and His Church over the dragon (Satan) and his helpers."

Berkenaan dengan penasiran kitab Wahyu, George Eldon Ladd sendiri sebagai salah satu ahli Perjanjian Baru mengakui bahwa, "Penafsiran kitab ini adalah yang paling sulit dan rumit dari semua kitab yang ada dalam Perjanjian Baru." Padahal seperti yang dikatakan Wilbur M. Smith: "Sistem penafsiran yang dianut seseorang akan sangat mempengaruhi pemahaman orang itu mengenai apa yang diajarkan oleh kitabini."

Secara umum ada empat sistem penafsiran dasar yang berbeda terhadap kitab Wahyu: penafsiran preteris, historis, futuris, dan simbolis atau idealis.

\section{a. Penafsiran Preteris.}

"Pandangan ini melihat simbolisme kitab Wahyu hanya berhubungan dengan kejadiankejadian pada saat ia ditulis." "Penafsirannya menekankan bahwa Wahyu adalah produkgereja yang sedang menghadapi ancaman penganiayaan yang dahsyat oleh bangsa Romawi." "Bagi penganut penafsiran preteris, kitab Wahyu tidak lagi berfungsi sebagai nubuat, dan sama saja dengan tulisan apokalips yang lain di waktu itu, misalnya IV Ezra." Pemikiran ini berdasakan alasan bahwa "sang pelihat dibuat ngeri oleh kemungkinan-kemungkinan terjadinya kejahatan yang melekat pada kekaisaran Romawi, dan ia memakai bahasa simbolis untuk memprotesnya, juga untuk menyatakan keyakinannya bahwa Allah akan campur tangan untuk memberlakukan apa yang sesuai dengan kehendak-Nya."

\section{b. Penafsiran Historis.}

"Kitab Wahyu, khususnya berbagai nubuat tentang materai, sangkakala dan cawan, mengemukakan berbagai peristiwa tertentu di dalam sejarah dunia yang berkaitan dengan kesejahteraan gereja sejak abad pertama hingga modern ini." Pandangan ini menganggap "Wahyu menyajikan cerita yang terus menerus tentang segenap periode sejarah." Sebagai konsekuensinya, sepertinya "setiap peristiwa penting dalam sejarah agama Kristen diberi bayangan secara luas, hingga kitab Wahyu menjadi semacam kalender peristiwa yang akan terjadi."

\section{c. Penafsiran Futuris.}

Meskipun kelompok ini melihat Wahyu sebagai kitab nubuatan, dan dalam proses penafsirannya lebih dikenal dengan harafiah, namun demikian kelompok ini tidaklah tunggal. Kaum futuris dibagi menjadi menjadi dua : futuris ekstrim dan futuris moderat.

Futuris ekstrim "menafsirkan kitab Wahyu menurut pernyataan dispensasinya tentang dua program ilahi yang berbeda, yaitu bagi Israel dan gereja. Segenap materai, sangkakala dan cawan adalah peristiwa-peristiwa yang akan terjadi pada masa kesusahan besar; dan karena hal ini adalah masa "sengsara bagi Yakub" (Yer.30:7), maka sesuai dengan definisinya, hal ini menyangkut Israel, dan bukan gereja." Kelompok ini lebih dikenal dengan nama dispensasionalis.

Futuris moderat "Wahyu dilihat sebagai gambaran penggenapan tujuan penebusan Allah, yang melibatkan hukuman dan keselamatan." Golongan ini dengan tegas mengambil posisi 
tentang kitab Wahyu: "Kitab Wahyu adalah kitab nubuat. Menyangkal kenyataan ini berarti menyangkal gaya penulisan, tema dan berbagai peristiwa yang disebutkan dalam kitab ini."

"Skema penafsiran futuris menandakan bahwa sebagian besar penglihatan di dalam kitab ini akan digenapi menjelang dan ketika mencapai akhir zaman." Futuris moderat menolak pendapat futuris ekstrim yang dianggap "melangkah demikian jauh sehingga mengatakan bahwa ketujuh jemaat Asia akan ditata dan didirikan ulang pada akhir zaman ini ketika nubuat tentang mereka akan digenapi - pandangan ini sepenuhnya tidak perlu dan tidak masuk akal."

\section{d. Penafsiran Simbolis atau Idealis.}

"Pandangan ini menandaskan bahwa tujuan Wahyu ialah menopang orang-orang Kristen yang teraniaya dan menderita untuk bertahan sampai akhir hidup mereka." Golongan ini "melihat Wahyu sebagai buku yang hanya berisi lambang-lambang mengenai kuasa-kuasa rohani yang bekerja dalam dunia. Berita buku Wahyu memberi kepastian kepada orang-orang saleh yang menderita tentang kemenangan akhir dari Allah dan tidak mengandung prediksi tentang peristiwa-peristiwa konkret di masa lampau atau di masa yang akan datang."

Menurut kelompok ini "tujuan penulisan kitab Wahyu bukan membina gereja mengenai masa depan, bukan untuk menubuatkan berbagai peristiwa tertentu, tetapi sekadar untuk mengajarkan sejumlah prinsip rohani yang mendasar."

\section{Misteri Milenium.}

Secara tertulis istilah milenium hanya ditemukan di Wahyu 20:1-7. Kata seribu tahun disebut sebanyak enam kali. Kata Latin "millennium" berarti seribu tahun, berasal dari dua kata,"mille" artinya seribu dan "annus" yaitu tahun. Terminologi ini menunjuk kepada periode seribu tahun. Kata milenium dalam bahasa latin mempunyai tiga makna : "a. Menunjukkan angka bilangan $=1.000$ (seribu); b. Menunjukkan kedamaian negara, masa keemasan dan kemakmuran masyarakat; c. Dari sudut teologia kata ini menunjukkan iblis terikat selama seribu tahun, dan orang Kristen akan menjadi raja bersama Kristus selama seribu tahun."

Seperti yang dinyatakan George Eldon Ladd, "Ajaran ini (milenium) biasanya ditentang bukan dari segi eksegesenya, melainkan dari segi teologinya. Kitab Wahyu sama sekali tidak membahas ajaran teologi tentang kerajaan seribu tahun." Sehingga anggapan berdasarkan arti harafiah atau simbolik sangat menentukan konsep milenium. "Orang-orang yang hidup sesudah zaman para Rasul, dan seluruh Gereja sepanjang 300 tahun, telah memahami nas ini dalam arti harfiahnya yang jelas."

Untuk memahami makna teologis dari milenium, sebenarnya konsep tentang kerajaan mesianis yang terbatas merupakan pengharapan orang Yahudi. Mereka mengharapkan suatu keadaan yang lebih sempurna dari sekarang. Namun dalam konteks Perjanjian Baru hal ini tidak bisa diterapkan. "Gagasan-gagasan Yahudi ini tidak membantu penafsiran ajaran PB, karena PB tidak seperti orang-orang Yahudi, tidak berpikir tentang suatu zaman baru yang mulai hanya pada masa yang akan datang. Menurut PB, zaman baru itu sudah mulai dalam Kristus."

Secara harafiah kepentingan adanya milenium di bumi, menurut Peter H. Davids didasarkan pada tiga alasan: "Pertama, milenium merupakan ganjaran bagi para martir ( Wahyu 13:15). Sekarang mereka mendapatkan ganjaran, yakni kehidupan yang kekal dan memerintah bersama Kristus; Kedua, milenium menunjukkan kemenangan Kristus. Kekuasaan-Nya selama seribu 
tahun akan mempertahankan pemerintahan yang telah dianugerahkan Allah kepada-Nya dan yang sekarang tersembunyi di surga; Ketiga, milenium mempertahankan pemerintahan Allah yang benar, sejarah penebusan. Mungkinkah Allah tidak bisa memerintah dunia ini secara lebih baik dari umat manusia (dan Iblis) ? Milenium menunjukkan bahwa Allah dapat memerintah secara benar dan adil dalam sejarah. Dia tidak perlu mengakhiri sejarah begitu saja. Barangkali inilah saatnya orang akan mengalami pemerintahan adil yang telah ditolak oleh dunia ( tetapi sebenarnya dirindukan) sejak Kejatuhan manusia."

Secara figuratif " kitab Wahyu penuh dengan angka-angka simbolik. Karena itu jelas angka "seribu" yang digunakan di sini tidak bisa ditafsirkan secara harafiah. Seribu menggambarkan suatu periode yang genap, suatu periode yang sangat panjang yang panjangnya tidak dapat ditentukan."

Sebenarnya diantara para ahli Perjanjian Baru memiliki pemahaman yang sama tentang pemerintahan Kristus atas umat-Nya. Namun yang menjadi masalah tetap pada arti harafiah dan figuratifnya milenium. Bagi $G$. E. Ladd: "Apa pun latar belakang historis di balik konsep ini, kita masih harus mengajukan pertanyaan tentang segi kepentingan teologisnya dalam Perjanjian Baru. Di sini kita tidak menemukan petunjuk, karena Perjanjian Baru tidak pernah menjelaskan tentang perlunya kerajaan sementara ini, kecuali hanya menyebutkan bahwa ini penting dalam mewujudkan pemerintahan Kristus ( I Kor 15:24 dst). Sebenarnya, inilah yang menjadi salah satu alasan teologis tentang pentingnya kerajaan yang demikian. Kristus sekarang sedang memerintah sebagai Tuhan dan Raja, namun pemerintahan-Nya masih terselubung, tidak kelihatan, dan tidak dikenal oleh orang-orang beriman. Pengertian dunia hanya melihat pemerintahan Kristus sebagai potensi yang belum terealisir. Jadi, jika masa sekarang adalah masa pemerintahan Kristus yang terselubung dan kemuliaan yang tersembunyi dan masa akan datang adalah masa pemerintahan Allah yang menyeluruh, maka kerajaan milenium adalah manifestasi kemuliaan Kristus ketika kekuasaan, yang sekarang telah dimiliki-Nya namun belum nampak, yang akan diserahkan-Nya kepada Bapa pada Masa yang Akan Datang, akan diperlihatkan secara nyata di dalam dunia." Kontradiksi dengan konsep ini Donald Gutrie menyatakan: "Memang, bahwa Kristus akan memerintah tidak dapat disangkal, karena hal ini didukung oleh perikop-perikop Perjanjian Baru lainnya ( I Kor 15:25; 2 Tim 2:12). Tetapi kita harus hati-hati, karena kerajaan seribu tahun hanya disebutkan dalam Wahyu 20:1-10 dan tidak disebutkan lagi dalam bagian PB lainnya. Dalam wahyu 20:1-10 itu konteksnya bersifat simbolik, yang berarti tidak dapat digunakan sebagai kunci untuk penafsiran perikop-perikop lain yang tidak bersikap simbolik."

\section{Seputar Pandangan Milenium}

Sepanjang perjalanan gereja, cara melihat milenium telah melahirkan empat arus utama : postmilenialisme, amilenialisme, premilenialisme dan dispensasionalisme. Keempat pandangan ini sama-sama mengklaim memiliki alasan-alasan penafsiran dan teologi Alkitab yang solid.

a. Postmilenialisme.

Paham ini berpendapat bahwa masa milenium dalam Wahyu 20 bersifat simbolis. Milenium adalah periode waktu yang lama, dan belum tentu seribu tahun kalender : "I is an indenfinitely long period of time, perhaps much longer than a literal one thousand years." Postmilenialisme berpandangan bahwa milenium merupakan pengharapan akan periode perdamaian yang 
panjang di bumi sebagai kelanjutan dari transformasi Kristen: "The kingdom of God is now being extended in the world through the preaching of the gospel and the saving work of the Holy Spirit in the hearts of individuals, that the world eventually is to be Christianized and that the return of Christ is to occur at the close of a long period of righteousness and peace commonly called the millennium."

Pandangan postmileniasme tentang milenium merupakan puncak dari Kerajaan Allah dan perubahan yang terjadi oleh Injil. Bagi kaum postmilenialisme "Kerajaan Allah merupakan realitas dunia saat ini, dan bukan realitas surga di masa yang akan datang. Kerajaan Allah itu ada di sini pada saat ini dan akan di mulai oleh sebuah peristiwa yang besar. Kerajaan itu akan datang secara bertahap, dan hampir tidak dapat kita lihat atau rasakan." "Kerajaan itu bukan sebuah dunia atau daerah kekuasaan di mana Tuhan memerintah. Lebih tepatnya, kerajaan itu adalah pemerintahan Kristus dalam hati manusia." Mereka berpandangan optimis bahwa akan adanya perbaikan dunia, "Thus postmillennialism holds that Chtristianity is to become the controlling and transforming influence not only in the moral and spiritual life of some individuals, but also in the entire social, economic and cultural life of the nations." Dan pertobatan dari semua bangsa sebelum kedatangan Kristus, seperti yang jelaskan Loraeine Boettner : "On postmilenial principles a strong emphasis is thrown on the university of Christ's work redemtion, and hope is held out for the salvation of an incredibly large number of the race of mandkin. Since it was the world, or the race, which was the object of Christ's redemtion. This does not mean that every individual will be saved, but the race as will be saved. Kelompok ini percaya bahwa periode milenium akan diakhiri dengan parousia, yang disertai dengan kebangkitan orang mati dan penghakiman terakhir.

\section{b. Amillenialisme.}

Amilenialisme percaya bahwa " seribu tahun" di Wahyu 20 bukan hanya untuk masa akan datang saja tetapi sekarang dalam proses realisasinya. Pandangan ini menyakini bahwa milenium bersifat spiritual. Anthony A. Hoekema melihat masa seribu tahun dalam kitab Wahyu dari dua sudut: "Pertama, pengertian futuristik yang menunjuk kepada peristiwa-peristiwa yang akan terjadi disekitar kedatangan Kristus yang kedua kali. Bila asumsi yang dibangun dalam Wahyu 20 harus mengikuti apa yang dideskripsikan dalam Wahyu 19 dalam urutan kronologis. Maka pada hakekatnya harus diterima bahwa pemerintahan seribu tahun yang digambarkan dalam Wahyu 20:4 telah terjadi setelah kedatangan Kristus yang kedua kali yang digambarkan pada wahyu 19:11; Kedua, jika Wahyu 20:1-6 dilihat sebagai lukisan yang akan terjadi sepanjang sejarah gereja, yang dimulai dari kedatangan Kristus yang pertama, maka kita akan memiliki pengertian dari kerajaan seribu tahun dalam Wahyu dengan cara yang sangat berbeda seperti disebutkan sebelumnya.'

Aliran ini lebih berpijak pada bagian kedua dengan sistim penafsiran tentang kitab Wahyu yang dikenal dengan paralelisme progresif (progressive parallelism) yang dipertahankan oleh William Hendriksen dalam bukunya More than Conguerors. Menurut pandangan ini kitab Wahyu terdiri dari 7 bagian yang berjalan pararel satu dengan yang lain dan bagian-bagian ini juga menyatakan suatu perkembangan eskatologi. Setiap bagian melukiskan gereja dan dunia mulai dari kedatangan Kristus yang pertama hingga kedatangan Kristus kedua. Ketujuh bagian itu terbagi dalam tiga tema besar yang meliputi: pergumulan antara Kristus dengan gerejaNya, 
dan di pihak lain musuh-musuh Kristus dengan gereja, maka akan di dapat suatu kesimpulan bahwa parohan pertamakitab (Wahyu l-1l) melukiskan pergumulan di bumi, menggambarkan gereja yang dianiaya oleh dunia. Parohan kedua (Wahyu 12-19) memberikan kepada kita latar belakang rohani yang lebih mendalam dari pergumulan ini, menggambarkan penganiayaan dari gereja oleh naga (setan) dan antek-anteknya. Dalam terang penganalisaan ini dapat dilihat bagaimana penempatan bagian terakhir dari kita ini (Wahyu 20-22). Bagian terakhir ini menggambarkan penghakiman dari setan, dan nasib akhirnya. Karena setan adalah puncak dari musuh Kristus, maka ini menjadi alasan mengapa nasib akhirnya diceritakan terakhir.

Dengan metode penafsiran paralelisme progresif maka wahyu 20:1-6 sebenarnya terdiri dari dua bagian: Wahyu 20:1-3 menggambarkan setan yang terikat, dan Wahyu 20: 4-6 pemerintahan seribu tahun dari jiwa-jiwa bersama Kristus. Karena Wahyu 20-22 merupakan bagian terakhir dari tujuh bagian dalam kitab Wahyu, maka Wahyu 20:1-6 tidak menggambarkan apa yang terjadi setelah kedatangan Kristus yang kedua kali. Tetapi Wahyu 20:I membawa sekali lagi ke awal dari Perjanjian Baru. Sesungguhnya kekalahan setan dimulai dari kedatangan Kristus yang pertama, seperti yang telah dikatakan dengan jelas dalam Wahyu 12:7-9. Jadi pemerintahan seribu tahun yang digambarkan dalam Wahyu 20:4-6 terjadi sebelum kedatangan Kristus yang kedua kali sebagai bukti dari fakta bahwa penghakiman terakhir, yang dilukiskan dalam Wahyu 20:11-15 digambarkan sebagai sesuatu yang terjadi setelah pemerintahan seribu tahun. Tidak hanya di kitab Wahyu tetapi di dalam bagian mana pun di Perjanjian Baru penghakiman terakhir itu dihubungkan dengan kedatangan Kristus yang kedua kali ( Wahyu 22:12, Matius 16:27;25:31-32, Yudas 14-15, dan 2 Tes 1:7-10). Dari semua ini jelas bahwa pemerintahan seribu tahun dari Wahy 20:4-6 harus terjadi sebelum bukan setelah kedatangan Kritus yang kedua kali.

Wahyu 22:1-3 menggambarkan setan diikat selama seribu tahun dan dilemparkan ke jurang maut. Maksud dari pengikatan ini adalah untuk menjaganya agar tidak menipu bangsa-bangsa lagi hingga selesainya masa seribu tahun. Kitab Wahyu penuh dengan angka-angka simbolik. Karena itu jelas angka "seribu tahun" yang dimaksudkan disini tidak bisa ditafsirkan secara harafiah. Oleh sebabitu dapat dikatakan bahwa periode seribu tahun merupakan waktu antara kedatangan Kristus yang pertama dan seketika sebelum kedatangan-Nya yang kedua. Iblis sudah dikalahkan dan diikat pada waktu Yesus disalip. Orang-orang mati (martyr) yang hidup kembali ( Why 20:4), dimengerti secara rohani (bukan kebangkitan tubuh). Mereka ini, yang secara rohani hidup, memerintah bersama dengan Kristus di Sorga untuk masa seribu tahun.

Kaum Amillenialisme percaya bahwa Kerajaan Allah telah didirikan oleh Kristus pada waktu Dia ada di bumi. Kerajaan itu sudah beroperasi di dalam sejarah hingga sekarang dan pasti akan di genapi, disempurnakan di dalam kehidupan yang akan datang (inaugurated eschatology). Seperti dituturkan oleh Anthony A. Hoekema: "They understand the kingdom of God to be the reign of God dynamically active in human history throught Jesus Christ. Its purpose is to redeem God's people from sin and from demonic powers, and finally to establish the new heavens and the new earth. The kingdom of God means nothing less than the reign of God in Christ over his entire created universe." 


\section{c. Premilenialisme.}

Secara harafiah, premilenial berarti "sebelum milenium". Premilenialisme adalah ajaran yang menyatakan bahwa setelah kedatangan Yesus yang kedua kali, Ia akan memerintah di bumi selama seribu tahun sebelum penyempurnaan akhir karya pembebasan Allah dalam langit dan bumi baru. "Para penganut premilenialisme menggunakan hermeneutika yang relatif dan harfiah dalam menafsirkan kitab suci, khususnya mengenai apokaliptik. Ini berarti kata-kata tersebut diartikan secara harfiah jika hal ini tidak menimbulkan ketidaklogisan. Lebih lanjut para penganut premilenialisme menunjukkan kecenderungan yang kuat terhadap penafsiran Wahyu yang futuristik." "Memahami berita Wahyu berarti memahami peristiwa-peristiwa yang akan datang."

Wahyu 20:1-6 ditafsir secara harfiah dan progresif kronologis. Secara alamiah G.E. Ladd menyatakan: "The only place in the Bible that speaks of an actual millenium is the passage in Revelation 20:1-6. Any millennial doctrine must be based upon the most natural exegesis of the passage." "Progresif kronologis memandang Wahyu 20 sebagai kelanjutan dari Wahyu 19. Karena Wahyu 19 menggambarkan kedatangan Kristus yang kedua kali, maka Wahyu 20 pasti menceritakan kejadian-kejadian yang mengikuti kedatangan kedua tersebut. Kaum premilenialis menafsirkan pengikatan setan, milenium, dan kedua kebangkitan dalam Wahyu 20 secara harafiah."

Bagi premilenialisme "pemerintahan Kristus ada di bumi yang terbentuk oleh kedatanganNya yang kedua." Maksud teologis pemerintahan ini menurut G.E. Ladd: "Di mana kejahatan dibatasi dan kebenaran menguasai, yang tidak pernah terjadi sebelumnya - jika akan ada saat keadilan sosial politis dan ekonomi terwujud, saat manusia akan dapat diam bersama-sama dalam kedamaian dan kemakmuran di bawah pemerintahan Kristus - jika sebelum pengadilan terakhir, Allah masih mengaruniakan suatu suasana kehidupan sosial yang mendekati kesempurnaan kepada manusia - namun setelah periode kebenaran itu berakhir, hati manusia yang belum dilahirkan kembali terbukti masih tetap memberontak terhadap Allah, maka dalam pengadilan akhir tahta putih nanti setiap mulut akan tersumbat sehingga manusia akan tidak bisa berdalih lagi dan semuanya akan mengakui kemuliaan dan kebenaran Allah."

Kelompok ini percaya akan adanya dua kali kebangkitan orang mati : Pertama, pada permulaan kedatangan Kristus yang kedua pada sebelum milenium; Kedua, adalah pada akhir milenium.

\section{d. Dispensasionalisme.}

Kaum dispensasinalisme dikenal sangat harfiah dalam menafsir Alkitab, hal ini juga diperlakukan kepada kitab nubuatan. Suatu ungkapan terkenal sebagai slogan mereka: "Jika pengertian yang sederhana itu masuk akal, kita tidak perlu mencari pengertian lainnya."

Dispensasionalisme menafsir milenium sebagai suatu fakta kronologis dan harfiah. Peristiwa-peristiwa dalam Wahyu 19:11-20:15 secara kronologis disajikan dengan logis sesudah kedatangan yang kedua sebagaimana akibat sesudah sebab." John F Walvoord menegaskan:" Sebagaimana halnya Wahyu mengenai jangka waktu adalah wahyu ilahi yang langsung diberitakan kepada Yohanes, maka angka seribu tahun harus diambil sebagai angka yang harfiah karena hal itu diungkapkan oleh Allah sebagai jangka waktu peristiwa ini." 
Dalam beberapa hal (kronologis, harfiah dan futuristik) dispensasionalisme sama dengan premilenialisme, sehingga nama mereka sama didepannya. Premilenialisme historis yang biasa disebut premileanisme dan premilenialisme dispensasionalisme yang biasa disebut dispensasionalisme. Perbedaan dari keduanya adalah faktor keharfiahan dalam menafsir Alkitab, keterkaitan Perjanjian Lama, dan perbedaan antara Israel dengan gereja. John F. Walvoord sebagai salah satu tokoh golongan dispensasionalisme menyatakan: "Banyak bagian dalam Perjanjian Lama menekankan kenyataan bahwa Israel akan memiliki tempat yang utama. Menurut Yehezkiel 20:33-38, pada saat kedatangan yang kedua, Israel akan mengalami hukuman yang membersihkan, dan hanya orang-orang benar sajalah, yaitu sisa Israel, yang dalam Perjanjian Lama digambarkan sebagai istri yang tidak setia, sekarang akan dipersatukan kembali kepada Kristus dalam lambang pernikahan dan mengalami kasih Kristus ( Hos 1:10. 11;2:14-23)."

Bagi kalangan ini "arti milenium lebih dari sekedar seribu tahun masa pemerintahan Kristus di atas bumi. Milenium memiliki tempat yang jelas dan pasti dalam rencana Allah : pemulihan bangsa Israel ke dalam tempat kesayangan-Nya dalam rencana Allah dan pemenuhan janjijanji Allah terhadap gereja. Karena itu milenium benar-benar memiliki ciri Yahudi. Milenium adalah saat gereja benar-benar menjadi miliknya sendiri. Walaupun tujuan dari milenium ini kurang jelas dalam beberapa bentuk premilenialisme lainnya, dalam dispensasionalisme milenium merupakan bagian integral dari teologi dan pemahaman seseorang mengenai Alkitab. Banyak bagian dari nubuat masih tidak terpenuhi, dan milenium memberikan saat pemenuhan mereka."

Kelompok ini percaya bahwa parousia akan terjadi dua kali : Pertama, Yesus akan datang secara rahasia untuk orang-orang percaya dan membawa, mengalami pengangkatan selama 7 tahun; Kedua, Kristus akan datang bersama orang-orang percaya untuk memerintah selama seribu tahun Selama masa pengangkatan akan terjadi antiktris di bumi.

\section{Kerajaan Seribu Tahun: Nubuat dan Harafiah}

Setiap metode penafsiran dan cara pandang terhadap Wahyu, khususnya kerajaan seribu tahun merupakan suatu upaya untuk menghasilkan suatu ajaran yang solid. Namun demikian untuk memperoleh pemahaman yang dianggap mendekati pemahaman yang sebenarnya mengenai kerajaan seribu tahun di dalam Wahyu di perlukan suatu evaluasi. Suatu evaluasi yang tentunya berdasarkan tolak ukur keyakinan penulis ( paper ini) terhadap pemahaman milenium.

\section{Evaluasi Penafsiran Kitab Wahyu.}

Penafsiran preteris "menandaskan bahwa penulis hanya melukiskan berbagai peristiwa yang terjadi di bumi di kerajaan Roma pada zaman itu saja, khususnya menjelang akhir abad pertama. Hal ini sebenarnya menyangkal sifat nubuatnya, dan memaksa banyak pernyataan di dalamnya ke dalam sebuah pola yang terlalu sempit." " Pandangan ini mengakui hubungan Wahyu dengan pikiran-pikiran dan peristiwa-peristiwa sejarah pada masa itu, namun menyangkal adanya unsur nubuat mengenai masa yang akan datang." Menurut kelompok ini "kitab Wahyu tidak lagi berfungsi sebagai nubuat, dan sama saja dengan tulisan apokalips yang lain di waktu itu." 
Terhadap penafsiran historis "terlepas dari semua keberatan terhadap skema penafsiran ini, harus diakui bahwa skema ini tidak memberikan sebuah prinsip atau kriteria dasar melalui mana kita bisa menentukan dengan tepat peristiwa historis mana yang dimaksudkan di dalam nas tertentu. Hal ini telah mengakibatkan kekacauan dan pertentangan besar di kalangan penganut pandangan ini." "Kesulitan utama dalam pandangan ini adalah bahwa tak ada konsensus yang dicapai mengenai masalah-masalahnya apa sebenarnya yang terlihat oleh garis besar sejarah dalam kitab Wahyu ini."

Penafsiran Futuris, pandangan ini sungguh-sungguh menerima unsur nubuat dalam Wahyu (1:19; 4:1). "Keberatan utama atas pandangan ini ialah:pandangan ini cenderung memindahkan totalitas kitab itu dari tempatnya dalam sejarah. Tidak mudah memahami arti kitabitu bagi para pembacanya yang pertama seandainya kitab itu harus dimengerti dengan cara demikian." Apalagi bagi mereka yang termasuk Futuris Ekstrim. Terhadap kelompok ini "konflik besar dalam Wahyu adalah antara anti kristus dengan Israel, dan bukan antara anti kristus dengan gereja."

Penafsiran simbolis atau Idealis "Kebaikan metode penafsiran Idealis adalah karena ia memusatkan perhatian pembaca pada kebenaran etis dan rohani kitab Wahyu, bukan pada aspek simbolismenya yang mengundang perbantahan. Sebaliknya ia cenderung untuk meremehkan simbolismeitu sebagai suatu sarana nubuat. "Pengrohaniannya" telah melepaskan Wahyu dari seluruh nilai ramalannya, serta mengingkari seluruh kaitannya dengan segala pemenuhan sejarah yang pasti. Menurut teori ini, hari penghakiman tiba setiap kali suatu perkara moral yang besar diputuskan; ia bukan merupakan suatu puncak terakhir di mana Kristus yang ilahi menyatakan kerajaan-Nya yang nyata." "Keberatan terhadap pandangan ini adalah bahwa literatur apokaliptis selalu menggunakan simbolisme apokalipstis untuk menjelaskan peristiwa-peristiwa yang terjadi dalam sejarah; dan kita harus menganggap bahwa apokalips itu memiliki unsur ini sebagaimana buku-buku lain yang sejenis."

\section{Evaluasi Seputar Pandangan Milenium.}

Postmilenialisme berbicara mengenai Kerajaan Allah yang menembus seluruh dunia. " Posmilenialisme telah memberi perhatian yang benar terhadap tema Alkitab yang asli- dimensi masa kini dari Kerajaan Allah." "Setelah mengetahui bahwa Tuhan dan Raja kita hadir dan Ia tersedia bagi kita pada saat ini, maka gaya hidup kita harus ditandai keyakinan, optimisme, dan sikap agresif." Kelompok ini percaya bahwa bahwa melalui Injil dunia semakin baik dan menjadi Kristen. Namun demikian, sifat optimistik ini tidaklah realistis sesuai pandangan Alkitab bahwa Matius 24:9-14 menggambarkan bahwa kondisi rohani dan moral manusia semakin bobrok pada zaman akhir. Pada sisi yang lain "postmilenialisme memiliki kesulitan untuk mempertahankan supernaturalisme yang asli."

Amilenialisme "secara umum telah berusaha menerima hakikat literatur Alkitab secara serius dan telah mengajukan pertanyaan tentang apa yang disampaikan dalam lingkup budaya itu, menyadari bahwa simbolisme mungkin ada dan berfungsi walaupun hal tersebut tidak jelas. Dalam keadaannya yang terbaik, amilenialisme juga telah berusaha menentukan arti yang sebenarnya dari simbol-simbol dengan cara mempelajari budaya dan bukan menetapkan arti secara acak." Namun pada bagian lain, kelompok ini telah mengesampingkan bahkan kehilangan sifat nubuatan dari milenium. Wilbur M. Smith menegaskan : "Memang benar 
bahwa kitab ini mengajarkan prinsip-prinsip rohani ; kitab ini memberikan pesan yang menghibur di dalam jaminan tentang kemenangan Kristus. Tetapi seluruh isi kitab ini bertentangan dengan pandangan bahwa pesan tersebut tidak menyingkapkan masa depan yang sudah dinubuatkan."

Premilenialisme "telah menunjukkan kesungguhan eskhatologis yang lebih besar dibandingkan banyak wakil dari sistem lainnya." "Para penganut ini menganggap serius penafsiran Alkitab. Barangkali penyelidikan yang paling cermat dari teks-teks Alkitab yang relevan, dan khususnya kitab Wahyu, dilakukan oleh penganut premilenialisme. Hal ini dapat dikaitkan dengan pendekatan mereka yang lebih harafiah terhadap penafsiran nubuatan, sebuah pendekatan yang cenderung membuat seseorang menjadi lebih optimis mengenai adanya kemungkinan menentukan arti dari penulisan-penulisan ini.Jika kitab suci memiliki kuasa, kita harus mempertimbangkan penafsiran yang intensif ini (apapun alasannya) sebagai nilai yang sangat positif." Masalah yang memberikan keberatan terhadap analisa kaum ini adalah fokus milenium yang hanya ada pada Wahyu 20. Selain dianggap teologi yang dibangun kelompok ini tidak melihat secara utuh Alkitab, juga sepertinya terlalu mempermudah dan rentan kalau hanya satu nats Alkitab yang berbicara dan ditafsir apa adanya.

Dispensasionalisme dalam beberapa hal tertentu sama dengan premilenialisme, khususnya sifat nubuatan dari milenium. Pandangan ini juga sangat menaruh perhatian yang besar terhadap eskhatologi secara keseluruhan. Namun kelompok ini menerapkan hermeneutika "harafiah" secara lebih keras dan menyeluruh dibandingkan premilenialisme, dan hubungan Israel dengan milenium dan eskatologi secara umum dinilai berlebihan.

\section{Penilaian dan Pijakan Akhir.}

Setiap sistem penafsiran terhadap Wahyu merupakan upaya panjang dan serius. Masingmasing mencoba mencari cara dan landasan yang dianggap baik. Namun demikian perlu disadari bahwa setiap sistem tidaklah sempurna, masing-masing memiliki kelemahan dan kelebihan: Sangatlah baik mempertimbangkan apa yang disampaikan L.L Moris: "Tidak satu pun dari pandangan (penafsiran) di atas yang memuaskan. Barangkali pandangan yang tepat ialah harus menggabungkan nalar-nalar yang benar dari semua pandangan itu. Nalar presteris yang menonjol ialah makna dan peranan Wahyu bagi orang-orang pada zamannya kitabitu ditulis, dan apa pun pendapat kita tentang kitabitu, pengertian ini harus dipertahankan. Nalar kaum historis yang melihat Wahyu menjelaskan gereja dalam seluruh sejarahnya juga tidak dapat dilepaskan, halnya sama dengan pandangan futuris yang serius menerima kesungguhan berita tentang zaman akhir. Wahyu memang menekankan kemenangan terakhir dari Allah, juga peristiwa-peristiwa yang menggugah semangat untuk hidup bagi Allah dalam masamasa perlawanan berkecamuk sengit.

Posmilenialisme lebih menekankan pada aspek penafsiran historis, Amilinealisme kepada penafsiran simbolis atau Idealis. Meskipun keduanya mencoba memahami teks dan konteks secara menyeluruh, namun mereka melupakan esensi lain yang sebenarnya sangat fundamental dalam melihat Wahyu dan milenium sebagai nubuatan. Pada posisi yang lain premilenialisme dan dispensasionalisme mencoba memahami Wahyu dan milenium dalam kerangka futuristik sebagai suatu apokaliptik. Walaupun dispensasionalis terlalu harfiah sekali dalam melihat simbol-simbol yang ada pada Alkitab. 
Hal yang sangat mencolok dalam memahami Kerajaan Seribu Tahun adalah adanya konsep dan keterkaitan antara Kerajaan Allah dan Kerajaan Seribu Tahun. Postmilenialisme memahami Kerajaan Seribu Tahun sebagai kelanjutan Kerajaan Allah yang sempurna di bumi ini dengan waktu yang tidak terbatas. Amelianisme menyatakan bahwa Kerajaan Seribu Tahun adalah Kerajaan Allah yang di mulai dan dihitung sejak Kristus dan berakhir setelah kedatangan Kristus kedua. Premilianisme melihat bahwa Kerajaan Seribu Tahun adalah Kerajaan Allah yang terealisasi dibumi dalam makna harafiahnya. Konsep ini sama dengan dispensasionalisme, hanya mazbab yang terakhir ini sangat menekankan keterkaitan dengan arti Israel secara fisik.

Secara pribadi penulis (paper ini ) lebih condong ke premileanisme. Kitab Wahyu merupakan kitab nubuatan. Milenium adalah bagian dari nubuatan. Walaupun melihat milenium secara harafiah dalam bingkai futuristik, hal ini tidak berarti mengabaikan segi historis terhadap pembaca awal, yaitu jemaat mula-mula. Suatu nubuatan tidak selalu langsung terealisasi saat peristiwa berlangsung. Namun yang pasti memberikan penghiburan dan kekuatan secara rohani. Sedangkan mengenai pemakaian simbol-simbol dalam Wahyu, Warren W. Wiersbe memberikan alasan logis yang perlu diperhatikan: " Pertama, simbol-simbol sebagai "sandi-sandi rohani. "Jika ada pejabat Romawi yang mencoba menggunakan Wahyu sebagai bukti melawan orang Kristen, kitab ini akan menjadi suatu teka-teki dan hal yang membingungkan bagi mereka; Kedua, simbolisme tidak dilemahkan oleh waktu. Yohanes dapat menggambarkan "ungkapan-ungkapan" yang hebat dalam Wahyu Allah dan menyusunnya menjadi suatu drama yang mengasikkan yang selama berabad-abad telah membesarkan hati orang-orang kudus yang teraniaya dan menderita.; Ketiga, simbol bukan hanya menyampaikan informasi, melainkan juga menanamkan nilai-nilai dan membangkitkan emosi. Yohanes bisa saja menulis, "Seorang diktator akan memerintah dunia," tetapi ia menggambarkannya dengan binatang. Simbol ini berbicara lebih banyak daripada sekedar sebutan "diktator." Ketimbang menjelaskan suatu sistem dunia, Yohanes cukup memperkenalkan "Babel besar" akan menyampaikan kebenaran rohani yang dalam kepada para pembaca yang mengenal Perjanjian Lama."

Penafsiran terhadap milenium yang bersifat futuristik dan harafiah, bukan berarti mengesampingkan aspek-aspek lain dalam penyusunan teologi. Bagi premilenialisme, Wahyu memiliki kekhusussan tertentu yang berbeda dengan kitab lainnya, kekhasan Wahyu karena kitab ini pada dasarnya adalah kitab nubuatan. Sehingga faktor nubuatan harus menjadi pertimbangan utama. Peter H. Davids dengan baik mengemukakan : "Pengujian terhadap sebuah pandangan dapat dilakukan dengan melihat apakah pandangan tersebut menjelaskan data Kitab Suci dengan baik dan mempertahankan nilai-nilai yang Yohanes coba untuk mengajarkannya." Mengenai nilai-nilai seribu tahun yang hendak Yohanes sampaikan, Peter H. Davids berkata: "Pemerintahan iblis telah berakhir, ia telah diikat. Kristus akan memerintah ; kemenangan-Nya di atas kayu salib akan menjadi sempurna. Para martirnya akan mendapatkan ganjaran. Dan pemberontakan terhadap Allah akan berakhir." Premilenialisme berdasarkan konsistensi teologis Perjanjian Baru terutama dalam kaitannya dengan Kerajaan Allah seperti yang dikemukakan oleh George Eldon Ladd pada pembahasan misteri milinium di atas, pola penafsiran dan sifat dari nubuatan milenium, maka kerajaan seribu tahun itu berararti harafiah. 


\section{KEPUSTAKAAN}

\section{Ensiklopedi}

Ensiklopedi Alkitab Masa Kini Jilid A-L, GEL, Apokaliptik Jakarta : Yayasan Komunikasi Bina kasih/OMF, 1992

\section{Buletin}

Buletin Momentum 27, Amillenialisme, Anthony A.Hoekema. Jakarta : Lembaga Reformed Injili Indonesia, 1995.

\section{Artikel di Internet.}

Meitha Sartika," Empat Pandangan Mengenai Kerajaan Seribu Tahun," kristenonline.com. diakses tanggal 8 Mei 2007; tersedia di http:/www.kristenonline.com/ download/book/artikel2/4

\section{Buku-Buku}

Barclay, William. Pemahaman Alkitab Setiap Hari, Wahyu pasal 1-5. Jakarta: PT BPK Gunung Mulia, 2001.

Boettner, Loraine. The Millenium. USA: The Presbyterian and Reformed Publishing Company, 1984.

Clouse, Robert G. The Meaning Millenium, Loraine Boettner, Postmilenium. Illinois: InterVarsity Press, 1977.

Davids, Peter H. Ucapan yang Sulit dalam Perjanjian Baru. Malang : Seminary Alkitab Asia Tenggara, 2001.

Ericson, Millard J. Pandangan Kontemporer dalam Eskhatologi, Sebuah Studi tentang Milenium. Malang: Seminary Alkitab Asia Tenggara, 2000.

Feiffer, Charles F. P. dan Everett F. Horrison, Tafsiran Alkitab Wycliffe Vol.3 PB, Wilbur M. Smith, Wahyu. Malang:Yayasan Penerbit Gandum Mas, 2001.

Gutrie, Donald Teologi Perjanjian Baru 3. Jakarta: BPK Gunung Mulia, 1992.

Hendriksen, William. More Than Conqerors. Michigan : Baker Book House,1983.

Ladd, George Eldon. Teologi Perjanjian Baru Jilid 2. Malang : Yayasan Kalam Hidup, 1999.

Leon Morris, Leon. Teologi Perjanjian Baru 2.Malang: Yayasan Penerbit Gandum Mas

Nelson, Thomas. Christian Faith. USA : Thomas Nelson Publisher, 1995.

Tenney, Merril C. Survei Perjanjian Baru. Malang: Yayasan Penerbit Gandum Mas, 1997.

Walvoord,John F. Pedoman Lengkap Nubuat Alkitab. Bandung:Yayasan Kalam Hidup, 2003.

Wiersbe, Warren W. Wahyu - Berkemenangan Di Dalam Kristus. Bandung : Yayasan Kalam Hidup, 2002.

Wongso, Dr.Peter. Hermeneutika Eskhatologi.Malang : Seminari Alkitab Asia Tenggara, 1992. 